\title{
PEMBUATAN NITROSELULOSA DARI BERBAGAI PULP LARUT KOMERSIAL SEBAGAI BAHAN BAKU PROPELAN
}

\author{
Frederikus Tunjung Seta ${ }^{1}$, Susi Sugesty, Teddy Kardiansyah \\ Balai Besar Pulp dan Kertas, Jl. Raya Dayeuhkolot No. 132, Bandung \\ ${ }^{1}$ ftunjung@gmail.com
}

Diterima : 20 Mei 2014, Revisi akhir : 23 Oktober 2014, Disetujui terbit : 3 November 2014

\section{MAKING OF NITROCELLULOSE FROM VARIOUS COMMERCIAL DISSOLVING PULPS AS PROPELLANT RAW MATERIALS}

\begin{abstract}
One effort to overcome the limited cotton is the use of dissolving pulp or rayon pulp with high $\alpha$-cellulose content. The aim of this research is to study the nitration process of cellulose from various commercial dissolved pulp into nitrocellulose, which is a material for Propellant Nitro Cellulose (PNC). The most important parameter in the preparation of propellant is nitrogen level, which should be higher than 12,75\%. The dissolving pulps from softwood sulfite process (A), hardwood kraft process (B), and hardwood sulfite process $(C)$ were pre-treated before nitration process, namely ball mill, willey mill, and blender. Nitrocellulose was made using two types of formulas, which were formula one (HNO3:HNO3 Fumming:H2SO4 = 1:3:12) and formula two (HNO3:HNO3 Fumming:H2SO4 = 1:1.25:4). The results showed that the preparation of nitrocellulose from dissolving pulp A using blender pretreatment and formula two provided the highest nitrogen level (14.05\%). The burn test of nitrocellulose met the smokeless specifications. Furthermore, the functional groups test by FTIR showed the presence of nitro group.
\end{abstract}

Keywords: dissolving pulp, nitrocellulose, propellant, nitrogen content, nitration process

\section{ABSTRAK}

Salah satu upaya untuk mengatasi ketersediaan kapas yang terbatas adalah dengan menggunakan pulp larut atau pulp rayon yaitu pulp dengan kandungan $\alpha$-selulosa yang tinggi. Penelitian ini bertujuan untuk mencari formula dan bahan baku yang paling baik untuk pembuatan nitroselulosa sebagai bahan Propellant Nitro Cellulose (PNC) dengan menggunakan berbagai jenis pulp larut komersial. Parameter yang terpenting dalam pembuatan propelan adalah kadar nitrogen harus lebih dari 12,75\%. Sebelum proses nitrasi, dilakukan beberapa cara perlakuan awal yaitu menggunakan ballmill, willeymill, dan blender terhadap pulp larut dari jenis kayujarum proses sulfit (A), kayudaun proses kraft (B), dan kayudaun proses sulfit (C). Nitroselulosa dibuat menggunakan dua jenis formula yaitu formula 1 $\left(\mathrm{HNO}_{3}: \mathrm{HNO}_{3}\right.$ Fumming: $\left.\mathrm{H}_{2} \mathrm{SO}_{4}=1: 3: 12\right)$ dan formula $2\left(\mathrm{HNO}_{3}: \mathrm{HNO}_{3}\right.$ Fumming: $\left.\mathrm{H}_{2} \mathrm{SO}_{4}=1: 1,25: 4\right)$. Hasil penelitian menunjukkan bahwa pembuatan nitroselulosa dari pulp larut A dengan perlakuan awal blender dan menggunakan formula 2 memberikan kadar nitrogen yang paling besar yaitu sekitar $14,05 \%$. Sedangkan uji nyala nitroselulosa memenuhi spesifikasi smokeless dan uji gugus fungsi dengan FTIR menunjukkan adanya gugus nitro.

Kata kunci: pulp larut, nitroselulosa, propelan, kadar nitrogen, proses nitrasi

\section{PENDAHULUAN}

Pulp larut adalah pulp yang memliki kandungan selulosa tinggi hampir menyamai kapas dan digunakan untuk pembuatan produk turunan selulosa, seperti serat atau film (viskosa, lyocell), selulosa ester (asetat, propionat, butirat, nitrat), dan selulosa ester (karboksimetil, etil, metil selulosa) (Sixta, 2006). Sesuai dengan Standar Nasional Indonesia (SNI) nomor 
0938:2010 tentang spesifikasi pulp rayon atau dissolving pulp atau pulp larut, $\alpha$-selulosa yang terkandung dalam pulp larut minimal sebesar 94\%untuk bahan baku pembuatan serat rayon viskosa, sedangkan untuk pembuatan nitroselulosa dapat menggunakan pulp larut yang mengandung $\alpha$-selulosa yang lebih rendah. Pulp larut dapat dibuat dengan proses kraft maupun proses sulfit (Strunk, 2012) dan secara umum dapat berbahan baku dari kayudaun (hardwood) maupun kayujarum (softwood) (Jahan dkk., 2008). Proses kraft menggunakan larutan $\mathrm{NaOH}$ dan $\mathrm{Na}_{2} \mathrm{~S}$ sebagai larutan pemasak dan untuk pembuatan pulp larut sebelum proses $\mathrm{kraft}$ dilakukan prahidrolisis untuk melemahkan ikatan hemiselulosa, karena pada proses kraft kandungan hemiselulosa dipertahankan optimal. Proses sulfit menggunakan larutan pemasak $\mathrm{Na}_{2} \mathrm{SO}_{3}$ dapat melarutkan hemiselulosa dengan baik.

Pulp larut yang mempunyai reaktifitas tinggi mempunyai rantai selulosa yang pendek, berat molekul yang rendah, kadar hemiselulosa yang rendah, dan kadar ekstraktif yang kecil (Christoffersson, 2005). Penggunaan pulp larut di dunia saat ini lebih banyak untuk pembuatan rayon (63\%), sedangkan untuk penggunaan yang lain masih jauh lebih kecil yaitu selulosa asetat (16\%) dan nitroselulosa (4\%) (Flickinger dkk., 2011). Walaupun nitroselulosa mendapatkan porsi yang sangat kecil, akan tetapi nitroselulosa mempunyai kegunaan yang sangat beragam.

Nitroselulosa adalah bahan yang sangat mudah terbakar yang merupakan hasil reaksi antara selulosa dengan asam nitrat. Nitroselulosa memiliki nilai derajat polimerisasi $(n)=100$ 3500; berat molekul 459,28 - 594,28; memiliki warna putih dan agak kekuningan, berbau, mudah terbakar, densitas relatif $1,58-1,65$; titik lebur $160^{\circ} \mathrm{C}$ sampai dengan $170^{\circ} \mathrm{C}$ dan akan mudah terbakar pada suhu $170^{\circ} \mathrm{C}$. Nitroselulosa tidak larut dalam air, akan tetapi larutdalam keton, ester, alkohol, dan pelarut lainnya (Purnawan, 2010).

Pembuatan nitroselulosa meliputi tahapan nitrasi selulosa dengan larutan penitrasi yang terdiri dari campuran asam nitrat dengan katalis asam sulfat pekat, pemisahan nitroselulosa dari larutan penitrasi, pencucian dan penstabilan (Purnawan, 2010). Kadar nitrogen dalam nitroselulosa sangat penting karena mempunyai pengaruh yang besar terhadap viskositas, kelarutan dan menentukan penggunaan nitroselulosa. Nitroselulosa yang memiliki kadar nitrogen
10,7-12,3\% yang biasanya disebut sebagai INC (Industrial Nitro Cellulose) digunakan sebagai bahan film, plastic, dan pernis. Nitroselulosa yang memiliki kadar nitrogen lebih tinggi dari $12,75 \%$ dapat digunakan sebagai bahan oksidator pada pembuatan PNC (Propellant Nitro Cellulose) untuk isian pendorong proyektil amunisi kecil, sedang, dan besar (Vogelsanger dan Sopraneti, 2010). Menurut Vogelsanger dan Sopraneti (2010), kadar nitrogen merupakan faktor yang paling penting dalam pembuatan nitroselulosa. Kadar nitrogen tersebut dapat menggambarkan sebagian besar sifat fisik dan kimia nitroselulosa, diantaranya kadar energi, suhu pembakaran, kelarutan, massa jenis dan reaktivitas.

Penelitian nitroselulosa jenis INC (Industrial Nitro Cellulose) menggunakan pulp kertas komersial yang memiliki kadar $\alpha$-selulosa $87 \%$ telah dilakukan dalam skala laboratorium dan menghasilkan nitroselulosa dengan kadar nitrogen 10,7-11,6\%, dapat dihasilkan dengan variasi komposisi larutan penitrasi $\mathrm{H}_{2} \mathrm{SO}_{4} / \mathrm{HNO}_{3} /$ $\mathrm{H}_{2} \mathrm{O}=3,98 \mathrm{~mol} / 1,94-2,06 \mathrm{~mol} / 4,03-4,52 \mathrm{~mol}$ (Setiawan, 2009). Penelitian yang menghasilkan nitroselulosa jenis PNC menggunakan pulp larut komersial hasil-pemasakan menggunakan proses sulfit dan kraft serta bahan baku jenis kayu daun lebar dan kayu daun jarum belum pernah dilaksanakan. Propelan (PNC) ini sangat diperlukan dalam bahan pendorong roket padat, akan tetapi bahan baku utama nitroselulosa ini adalah kapas yang sumbernya sangat terbatas di Indonesia, oleh karena itu impor propelan Indonesia terus meningkat (Wibowo, 2005) (Miranda dkk., 2006).

Perlakuan awal penggilingan terhadap bahan baku pulp larut dilakukan untuk mengubah ukuran partikel menjadi lebih kecil dengan tujuan memperluas kontak permukaan. Dengan memperluas kontak permukaan pulp dengan reagen, diharapkan laju reaksi dapat berjalan lebih cepat. Perlakuan awal dapat dilakukan dengan menggunakan ballmill, blender, dan willeymill. Ballmill merupakan kontainer berbentuk tabung berisikan bola-bola kecil dari bahan keramik, yang akan saling bertumbukan saat berputar dengan kecepatan tertentu. Dengan adanya tumbukan bola-bola keramik tersebut pulp mengalami perubahan ukuran menjadi lebih kecil. Penelitian sebelumnya yang dilakukan oleh Miranda,dkk dengan memanfaatkan limbah kelapa sawit sebagai bahan baku nitroselulosa dengan kadar nitrogen 12,75\% (Miranda dkk.,2006). 
Penelitian yang dilakukan oleh Wirayuda (2011) menyatakan bahwa rejectpulpdapatmenghasilkan nitroselulosa, akan tetapi tidak disebutkan kadar nitrogen yang dihasilkan dari penelitian tersebut (Wirayuda, 2011). Penelitian-penelitian tersebut mempunyai kelemahan yaitu nitroselulosa dari bahan baku limbah kurang ketersediaannya sehingga penelitian ini memanfaatkan pulp larut yang ada di pasaran (komersial) sehingga diharapkan mampu menjaga keberlangsungan bahan baku apabila akan dimanfaatkan sebagai bahan nitroselulosa.

Tujuan dari penelitian ini adalah mencari formula dan bahan baku dari berbagai jenis pulp larut komersial untuk pembuatan nitroselulosa sebagai bahan PNC.

\section{BAHAN DAN METODE}

Penelitian ini dilaksanakan di laboratorium Derivat Selulosa Balai Besar Pulp dan Kertas, Bandung. Bahan baku yang digunakan dalam penelitian ini adalah pulp larut komersial jenis A (kayujarum proses sulfit), B (kayudaun proses kraft), dan C (kayudaun proses sulfit) yang didapatkan dari salah satu industri rayon di Purwakarta. Pulp larut tersebut mempunyai ukuran 40 x $40 \mathrm{~cm}$, viskositas 16,37 cP (pulp larut A), 15,98 cP (pulp larut B), dan 16,48 cP (pulp larut C).

Tahapan penelitian ini terdiri dari preparasi bahan baku, proses nitrasi dan analisis hasil. Pulp larut komersial yang diperoleh diperkecil ukurannya dengan tiga macam alat yaitu willeymill, ballmill atau blender. Blender yang digunakan adalah blender untuk bahan kering menggunakan pisau tumpul (waring blender), sedangkan willeymill merupakan alat penggilingan yang dilengkapi dengan rotor blade.

Pulp hasil dari ketiga perlakuan kemudian disaring menggunakan sieve shaker dengan ukuran saringan 200 mesh dan 60 mesh. Pulp yang tidak lolos 200 mesh tidak digunakan dalam penelitian ini. Setelah mendapatkan ukuran partikel yang diinginkan, pulp dikeringkan di dalam oven pada suhu $105^{\circ} \mathrm{C}$ selama lebih kurang satu hari sampai kadar air tidak lebih dari $2 \%$. Pulp larut dianalisis derajat polimerisasi, viskositas, kadar air, $\alpha$-selulosa, dan kadar abu. Analisis tersebut menggunakan metode yang tercantum pada Tabel 1 .

Proses nitrasi menggunakan reagen asam nitrat $\left(\mathrm{HNO}_{3}\right) 65 \%$, asam nitrat fumming, dan sebagai katalis berupa asam sulfat $\left(\mathrm{H}_{2} \mathrm{SO}_{4}\right)$. Formula yang digunakan pada penelitian ini merupakan hasil penelitian yang dilakukan oleh Setiawan dkk. (2009). Komposisi bahan kimia yang digunakan dapat dilihat pada Tabel 2.

Tabel 1. Metode Analisis Pulp larut

\begin{tabular}{|c|c|c|}
\hline No. & Parameter & Metode \\
\hline 1. & $\begin{array}{l}\text { Kadar Abu: Kertas, Karton } \\
\text { dan Pulp-Cara Uji Kadar } \\
\text { Abu pada } 900{ }^{\circ} \mathrm{C}\end{array}$ & $\begin{array}{l}\text { SNI ISO } \\
2144: 2010\end{array}$ \\
\hline 2. & $\begin{array}{l}\text { Kadar Air: Cara Uji Kadar } \\
\text { Air Pulp dan Kayu dengan } \\
\text { metode Pemanasan dalam } \\
\text { Oven }\end{array}$ & $\begin{array}{l}\text { SNI 08-7070- } \\
\quad 2005\end{array}$ \\
\hline 3. & $\begin{array}{l}\text { Kadar } \alpha \text {-selulosa: Pulp- Cara } \\
\text { Uji Kadar Selulosa alfa, beta } \\
\text { dan gamma }\end{array}$ & $\begin{array}{l}\text { SNI -0444- } \\
\quad 2009\end{array}$ \\
\hline 4. & $\begin{array}{l}\text { Viskositas: Pulp- Cara } \\
\text { Uji Viskositas dalam } \\
\text { Kuprietilendiamina }\end{array}$ & $\begin{array}{l}\text { SNI } 0936 \text { : } \\
\quad 2008\end{array}$ \\
\hline 5. & $\begin{array}{l}\text { DP: Pulp-Cara Uji Bilangan } \\
\text { Viskositas Limit (Viskositas } \\
\text { Intrinsik) dalam Larutan } \\
\text { Kuprietilendiamina (CED) }\end{array}$ & $\begin{array}{l}\text { SNI ISO } \\
5351: 2012\end{array}$ \\
\hline 6. & $\begin{array}{l}\text { S 18: Pulp-Cara Uji } \\
\text { Kelarutan dalam Alkali }\end{array}$ & $\begin{array}{l}\text { SNI ISO } \\
692: 2010\end{array}$ \\
\hline
\end{tabular}

Tabel 2. Formula Larutan Penitrasi

\begin{tabular}{cccc}
\hline \multirow{3}{*}{ Formula } & \multicolumn{3}{c}{ Perbandingan Reagen } \\
\cline { 2 - 4 } & $\mathrm{HNO}^{3}$ & $\mathrm{HNO}_{3}$ & $\mathrm{H}_{2} \mathrm{SO}_{4}$ \\
\hline 1 & $65 \%$ & Fumming & 12 \\
2 & 1 & 3 & 12 \\
\hline
\end{tabular}

Sumber: Setiawan (2009)

Lima gram pulp yang telah diketahui kadar airnya dimasukkan secara perlahan ke dalam larutan penitrasi sesuai formula yang digunakan sambil diaduk sampai pulp masuk seluruhnya dan diamkan selama satu jam. Kondisi nitrasi harus dipertahankan pada suhu sekitar $10^{\circ} \mathrm{C}$. Nitroselulosa yang dihasilkan dicuci dengan aquades dan natrium bikarbonat sampai $\mathrm{pH}$ netral untuk menghentikan reaksi nitrasi. Setelah $\mathrm{pH}$ netral, nitroselulosa dicuci dengan etanol bersuhu $40-50^{\circ} \mathrm{C}$ untuk menghilangkan air, kemudian disaring dan disimpan dengan cara merendamnya dalam etanol menggunakan botol berwarna gelap, sebelum dilakukan karakterisasi. 
Karakterisasi dasar nitroselulosa yaitu penentuan kadar nitrogen, sedangkan analisis gugus fungsi menggunakan FTIR (Fourier Transform Infra Red)-Shimadzu dan uji nyala sebagai pelengkap untuk meyakinkan bahwa gugus nitrat telah berikatan dengan selulosa (Hartaya, 2009; Hartaya, 2010; Vogelsanger dan Sopranetti, 2010). Metode yang digunakan untuk analisis nitrogen adalah metode mikrokjedahl dengan menggunakan katalis asam salisilat dan natrium sulfat (Amin dan Flowers, 2004). Digester dan alat destilasi yang digunakan untuk metode mikrokjedahl merupakan produksi dari VELP, sedangkan untuk titrasi dilakukan secara manual. Analisis FTIR dilakukan di Institut Pertanian Bogor (IPB), dan analisis uji nyala dilakukan di Balai Besar Pulp dan Kertas (BBPK) Bandung.

Uji nyala dilakukan dengan mengambil sedikit nitroselulosa kemudian nitroselulosa tersebut dibakar dengan sumber api, dan dilihat apakah nitroselulosa tersebut menghasilkan sedikit asap dan menyisakan abu setelah dibakar (Hartaya, 2009).

\section{HASIL DAN PEMBAHASAN}

\section{Karakteristik Pulp Larut}

Karakteristik ketiga jenis pulp larut komersial dapat dilihat pada Tabel 3. Dari Tabel 3 dapat dilihat bahwa viskositas dan derajat polimerisasi tertinggi diperoleh dari pulp larut $\mathrm{A}$, hal ini dikarenakan pulp larut A berasal dari bahan baku kayujarum dengan proses sulfit. Kayujarum memiliki serat/rantai selulosa yang lebih panjang daripada kayudaun. Proses sulfit yang digunakan akan menghasilkan pulp larut dengan kadar hemiselulosa yang lebih rendah dari pada proses kraft.
Pada Tabel 3 terlihat bahwa contoh B yaitu pulp larut berbahan baku kayudaun proses Kraft mempunyai kadar abu, $\alpha$-selulosa dan kelarutan dalam alkali $18 \%$ (S18) yang tinggi tetapi viskositas dan derajat polimerisasi yang lebih rendah.

\section{Hasil Analisis Kadar Nitrogen}

Hasil analisis kadar nitrogen tercantum pada Tabel 4. Kadar nitrogen nitroselulosa yang paling tinggi di atas $12,75 \%$ (Vogelsanger dan Sopranetti, 2010) diperoleh dari pulp larut A dengan perlakuan blender dan menggunakan formula $2 \quad\left(\mathrm{HNO}_{3}: \mathrm{HNO}_{3}\right.$ fumming: $\mathrm{H}_{2} \mathrm{SO}_{4}=$ $1: 1,25: 4)$ yaitu $14,05 \%$. Penggunaan blender menghasilkan kadar nitrogen yang paling tinggi dibanding dengan willeymill dan ballmill, karena pada proses blender dihasilkan partikel dengan ukuran yang lebih kecil dan pada saat proses nitrasi pulp tersebut akan mengembang (swelling), sehingga proses nitrasi lebih optimal dibanding perlakuan lainnya.

Kadar nitrogen yang diperoleh lebih tinggi dari hasil penelitian Setiawan (2009)yang menghasilkan kadar nitrogen $11,08 \%$ dengan bahan baku kayudaun proses kraft. Pulp dengan proses kraft memiliki kadar selulosa yang lebih tinggi tetapi DP lebih lebih rendah, karena di dalam proses kraft terdapat $\mathrm{Na}_{2} \mathrm{~S}$ yang dapat menghambat degradasi selulosa. Sedangkan pada proses sulfit, kondisi asam akan mendorong pemecahan ikatan glikosidik pada hemiselulosa dan selulosa, hemiselulosa yang memliki ikatan glikosidik yang lebih lemah akan dapat dengan mudah didegradasi dibandingkan dengan selulosa (Strunk, 2012). Pulp larut dengan proses kraft dibandingkan dengan proses sulfit pada kondisi lignin yang sama akan mengandung kadar selulosa yang lebih besar. Perlakuan

Tabel 3. Hasil Analisis Pulp Larut

\begin{tabular}{ccccc}
\hline No. & \multirow{2}{*}{ Karakteristik } & $\begin{array}{c}\text { Pulp Larut } \\
\text { A }\end{array}$ & $\begin{array}{c}\text { Pulp Larut } \\
\text { B }\end{array}$ & $\begin{array}{c}\text { Pulp Larut } \\
\text { C }\end{array}$ \\
\hline 1. & Abu (\%) & 0,11 & 0,60 & 0,13 \\
2. & $\alpha$-selulosa (\%) & 88,16 & 92,49 & 89,40 \\
3. & S18 (\%) & 3,40 & 5,86 & 4,70 \\
4. & Viskositas (cP) & 11,38 & 9,90 & 10,24 \\
5. & DP & 1342 & 902,0 & 944,1 \\
\hline
\end{tabular}


terhadap pulp A dengan blender menghasilkan kadar nitrogen nitroselulosa paling tinggi sedangkan perlakuan dengan ballmill paling rendah (7,69\%). Dari Tabel 4 dapat dilihat bahwa perbandingan asam dalam campuran sangat berpengaruh terhadap kadar nitrogen dalam produk, dimana $\mathrm{H}_{2} \mathrm{SO}_{4}$ selain sebagai katalis juga sebagai dehydrating agent yang berfungsi sebagai pengikat air yang terbentuk pada reaksi nitrasi. Pada penggunaan $\mathrm{H}_{2} \mathrm{SO}_{4}$ yang lebih rendah (formula 1), semakin banyak air yang tidak terikat akan menghambat substitusi gugus -OH oleh gugus $\mathrm{NO}_{2}$. Sebaliknya, jika jumlah $\mathrm{H}_{2} \mathrm{SO}_{4}$ semakin besar (formula 2), maka $\mathrm{H}_{2} \mathrm{SO}_{4}$ sebagai katalis dapat menurunkan energi aktivasi yang secara langsung dapat mempercepat laju reaksi, sehingga kadar nitrogen akan semakin tinggi sampai perbandingan optimum tercapai.
$\mathrm{H}_{2} \mathrm{SO}_{4}$ yang berlebih akan mendestruksi selulosa sehingga selulosa yang bereaksi menjadi lebih kecil, demikian pula penggunaan $\mathrm{HNO}_{3}$ yang semakin besar akan menyebabkan reaksi bergeser ke arah pembentukan produk.

\section{Uji Nyala Nitroselulosa}

Hasil uji nyala seperti yang yang terlihat pada Tabel 5, 6 dan Gambar 1, menunjukkan bahwa pulp A dengan perlakuan blender dan tanpa proses nitrasi menghasilkan abu pada akhir uji nyala dan berasap, sedangkan nitroselulosa dengan perlakuan ketiga jenis pulp larut dan perlakuan awal dengan menggunakan willeymill, ballmill dan blender akan menghasilkan nyala api yang tidak meninggalkan sisa abu setelah hasil pembakaran, mengeluarkan asap yang sedikit

Tabel 4. Hasil Analisis Kadar Nitrogen

\begin{tabular}{|c|c|c|c|c|}
\hline \multirow{2}{*}{ No. } & \multirow{2}{*}{ Perlakuan } & \multirow{2}{*}{ Jenis Pulp } & \multicolumn{2}{|c|}{ Kadar Nitrogen (\%) } \\
\hline & & & Formula 1 & Formula 2 \\
\hline 1. & & A & 13,28 & 14,05 \\
\hline 2. & Blender & B & 12,94 & 13,87 \\
\hline 3. & & $\mathrm{C}$ & 12,35 & 13,79 \\
\hline 4. & & A & 10,88 & 11,55 \\
\hline 5. & Willeymill & B & 10,55 & 11,21 \\
\hline 6. & & $\mathrm{C}$ & 12,15 & 13,62 \\
\hline 7. & & A & 7,69 & 12,58 \\
\hline 8. & Ballmill & B & 11,73 & 11,52 \\
\hline 9. & & $\mathrm{C}$ & 12,26 & 12,16 \\
\hline
\end{tabular}

Tabel 5. Hasil Uji Nyala Nitroselulosa Formula 1

\begin{tabular}{ccccc}
\hline \multirow{2}{*}{ No. } & \multirow{2}{*}{ Perlakuan } & Sample Pulp & \multicolumn{2}{c}{ Uji Bakar } \\
\cline { 3 - 5 } & & Terbakar & Keterangan \\
\hline 1. & & A Tanpa Nitrasi & $\sqrt{ }$ & Meninggalkan abu dan berasap \\
2. & \multirow{2}{*}{ Blender } & $A$ & $\sqrt{ }$ & Tidak meninggalkan abu dan tidak berasap \\
3. & $B$ & $\sqrt{ }$ & Tidak meninggalkan abu dan tidak berasap \\
4. & & $C$ & $\sqrt{ }$ & Tidak meninggalkan abu dan tidak berasap \\
\hline 5. & & $\sqrt{ }$ & Tidak meninggalkan abu dan tidak berasap \\
6. & Willeymill & $B$ & $\sqrt{ }$ & Tidak meninggalkan abu dan tidak berasap \\
7. & & $C$ & $\sqrt{ }$ & Tidak meninggalkan abu dan tidak berasap \\
\hline 8. & & $A$ & $\sqrt{ }$ & Tidak meninggalkan abu dan tidak berasap \\
9. & Ballmill & $B$ & $\sqrt{ }$ & Tidak meninggalkan abu dan tidak berasap \\
10. & & $C$ & $\sqrt{ }$ & Tidak meninggalkan abu dan tidak berasap \\
\hline
\end{tabular}


Tabel 6. Hasil Uji Nyala Nitroselulosa Formula 2

\begin{tabular}{ccccc}
\hline \multirow{2}{*}{ No. } & Perlakuan & Sample Pulp & \multicolumn{2}{c}{ Uji Bakar } \\
\cline { 3 - 5 } & & Terbakar & Keterangan \\
\hline 1. & A Tanpa Nitrasi & $\sqrt{ }$ & Meninggalkan abu dan berasap \\
2. & \multirow{2}{*}{ Blender } & $A$ & $\sqrt{ }$ & Tidak meninggalkan abu dan tidak berasap \\
3. & $B$ & $\sqrt{ }$ & Tidak meninggalkan abu dan tidak berasap \\
4. & & $C$ & $\sqrt{ }$ & Tidak meninggalkan abu dan tidak berasap \\
\hline 5. & & $A$ & $\sqrt{ }$ & Tidak meninggalkan abu dan tidak berasap \\
6. & Willeymill & $B$ & $\sqrt{ }$ & Tidak meninggalkan abu dan tidak berasap \\
7. & & $C$ & $\sqrt{ }$ & Tidak meninggalkan abu dan tidak berasap \\
\hline 8. & & $A$ & $\sqrt{ }$ & Tidak meninggalkan abu dan tidak berasap \\
9. & Ballmill & $B$ & $\sqrt{ }$ & Tidak meninggalkan abu dan tidak berasap \\
10. & & $C$ & $\sqrt{ }$ & Tidak meninggalkan abu dan tidak berasap \\
\hline
\end{tabular}

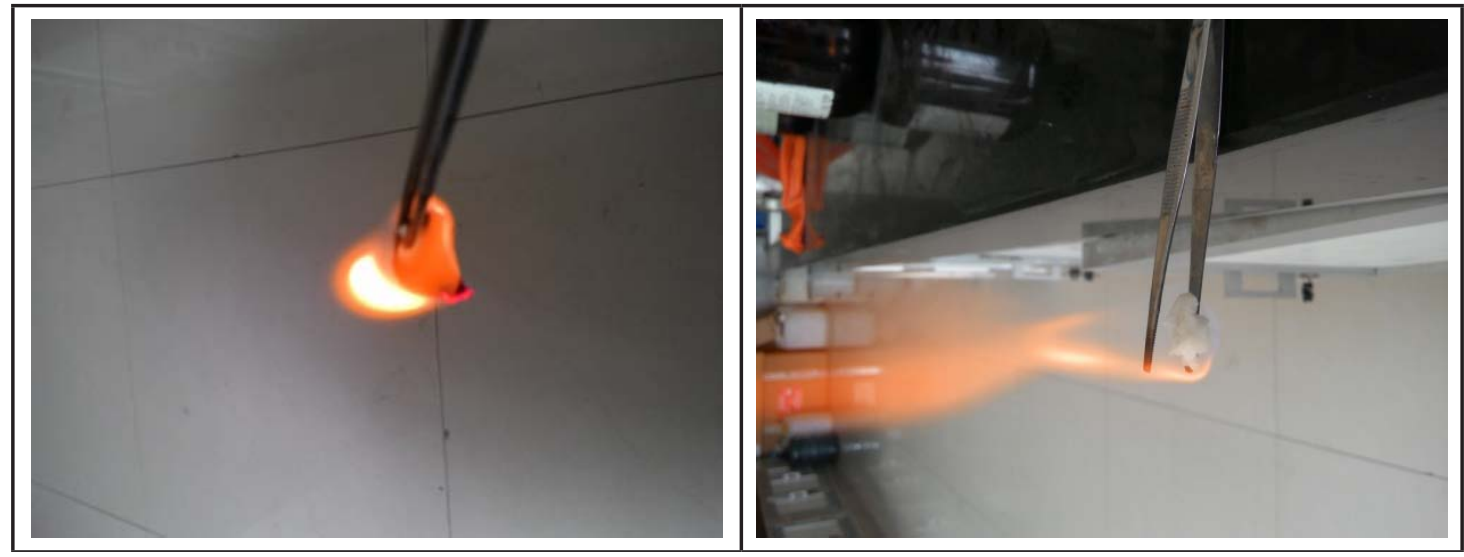

(a)

(b)

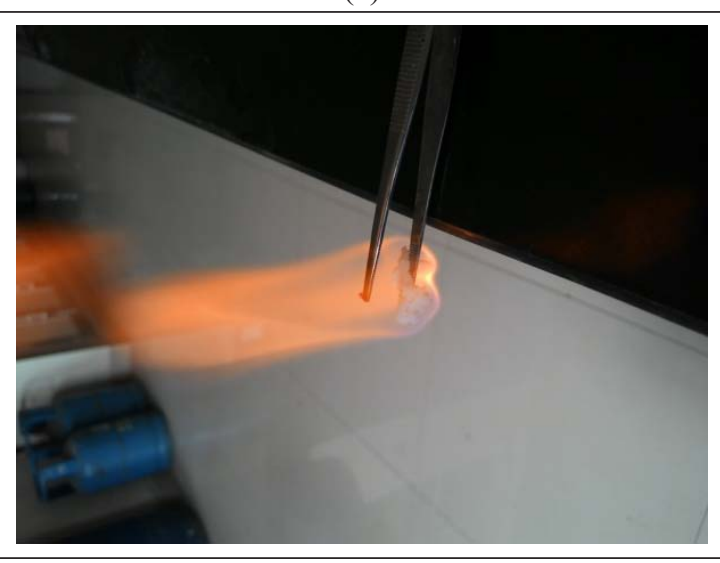

(c)

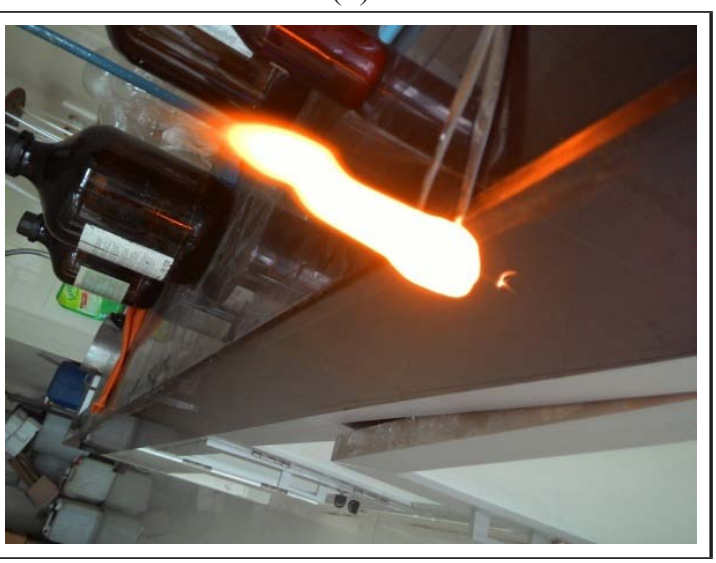

(d)

Gambar 1. Uji Nyala Pulp Larut A sebelum Nitrasi dengan Perlakuan Blender (a) dan Nitroselulosa dari Pulp Larut A dengan Perlakuan Blender (b) Willeymill (c), dan Ballmill (d) 
(smokeless) dan terdapat percikan bunga api saat dinyalakan (Purnawan, 2010). Oleh karena itu pembuatan nitroselulosa dari ketiga jenis pulp larut dan ketiga jenis pre-treatment memenuhi spesifikasi smokeless. Hal itu dikarenakan pada nitroselulosa terdapat gugus $-\mathrm{NO}_{2}$ yang dapat dibuktikan pada uji gugus FTIR. Nitroselulosa membutuhkan panas pembakaran yang lebih kecil dibandingkan selulosa, hal itu mengakibatkan masih terdapatnya sisa pembakaran pada selulosa sedangkan pada nitroselulosa bisa terbakar habis, menurut Poumortazavi, kadar nitrogen akan mempengaruhi energi aktivasi (Pourmortazavi dkk., 2009).

\section{Uji Gugus Fungsi dengan FTIR}

Pengamatan terhadap spektrum inframerah nitroselulosa berbahan baku ketiga jenis pulp larut dan ketiga jenis perlakuan awal menunjukkan kurva FTIR yang identik. Pada Gambar 2, 3, 4 dan 5 dapat dilihat perbedaan kurva FTIR antara nitroselulosa dan bahan baku yang dalam hal ini diwaliki oleh nitroselulosa dan pulp bahan baku jenis B formula 2 ; perlakuan blender dan ballmill menunjukkan perubahan tinggi, dan besar puncak serapan pada bilangan panjang gelombang sekitar 3000 sampai $3500 \mathrm{~cm}^{-1}$ dengan nilai transmitant yang tinggi untuk nitroselulosa. Bilangan gelombang tersebut mengindikasikan bahwa gugus $\mathrm{OH}$ dari selulosa $\mathrm{CH}$ stretching telah mengalami perubahan. Serapan inframerah yang paling spesifik untuk nitroselulosa ini adalah timbulnya puncak serapan dengan bilangan panjang gelombang sekitar $1600 \mathrm{~cm}^{-1}$ R-O-NO, $1400 \mathrm{~cm}^{-1} \quad \mathrm{R}-\mathrm{NO}_{2}$ dan, $600 \mathrm{~cm}^{-1} \mathrm{R}-\mathrm{NO}_{2}$ atau $\mathrm{R}-\mathrm{O}-\mathrm{NO}_{2}$. Adanya gugus nitril ini memberikan kesimpulan penting tentang unsur fungsional dalam struktur nitroselulosa, yang menunjukkan bahwa telah terjadi proses nitrasi.

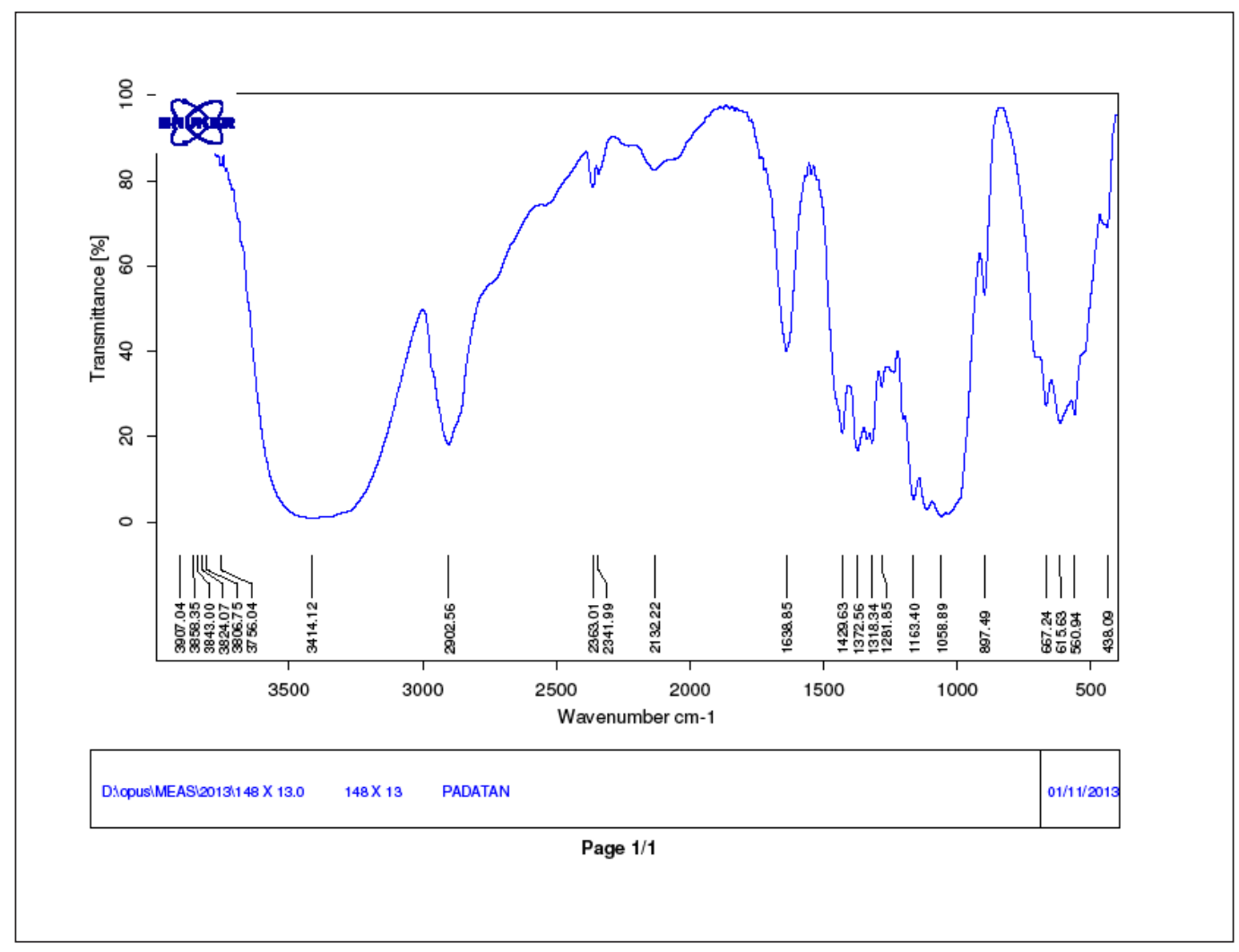

Gambar 2. Kurva FTIR untuk Pulp Larut B Perlakuan Blender 


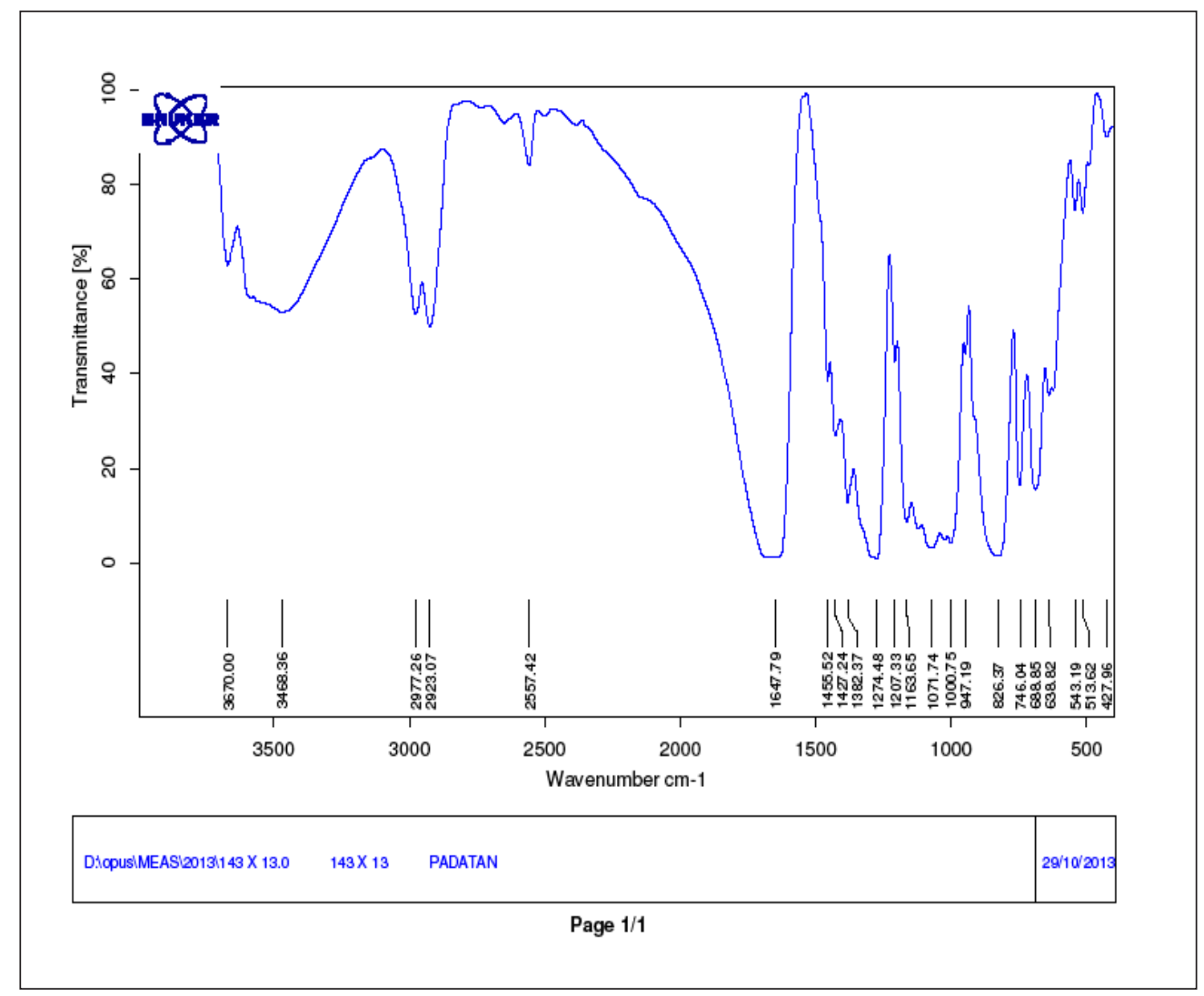

Gambar 3. Kurva FTIR untuk Nitroselulosa dari Pulp Larut B Perlakuan Blender (b)

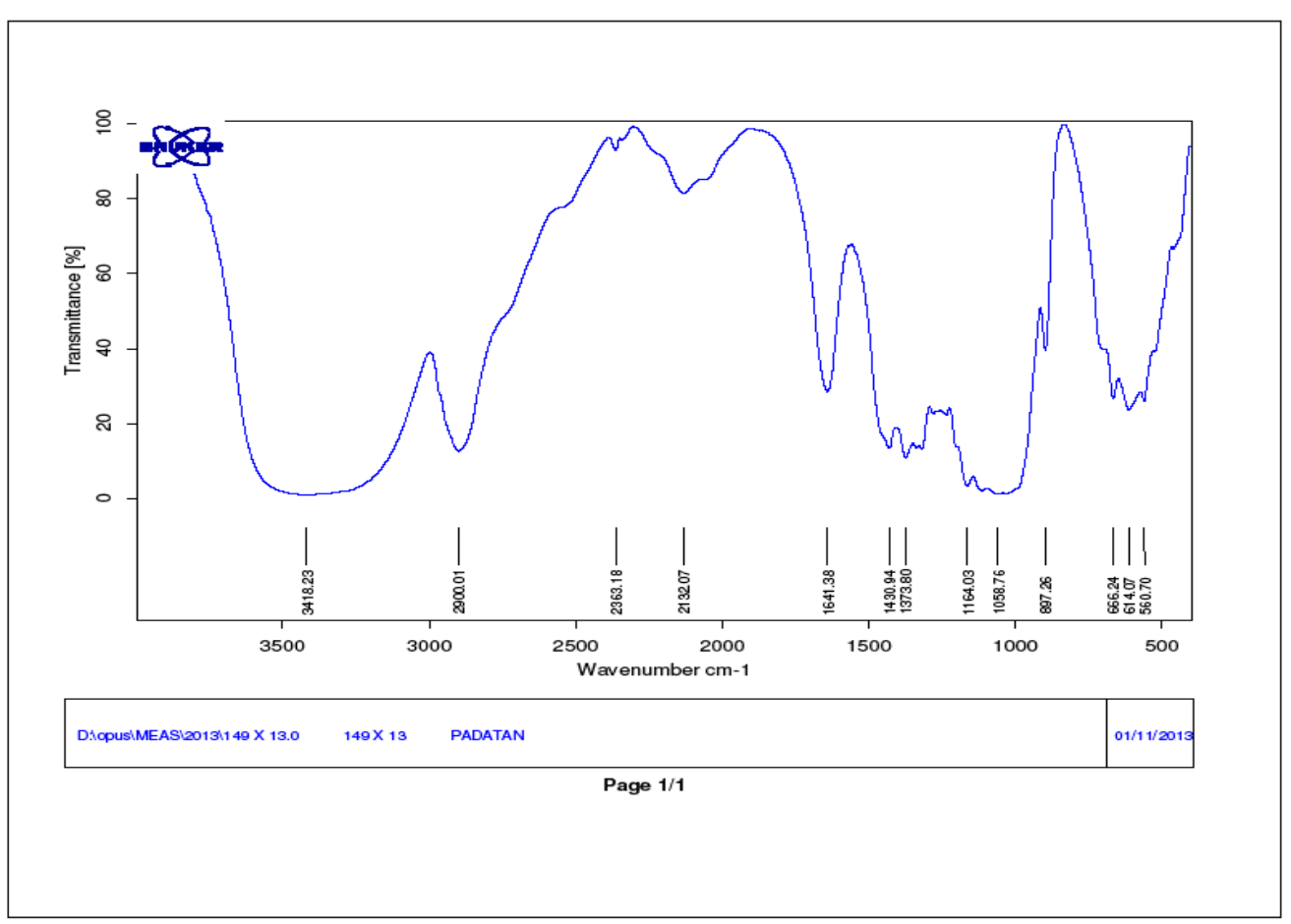

Gambar 4. Kurva FTIR untuk Bahan Baku Ballmill 


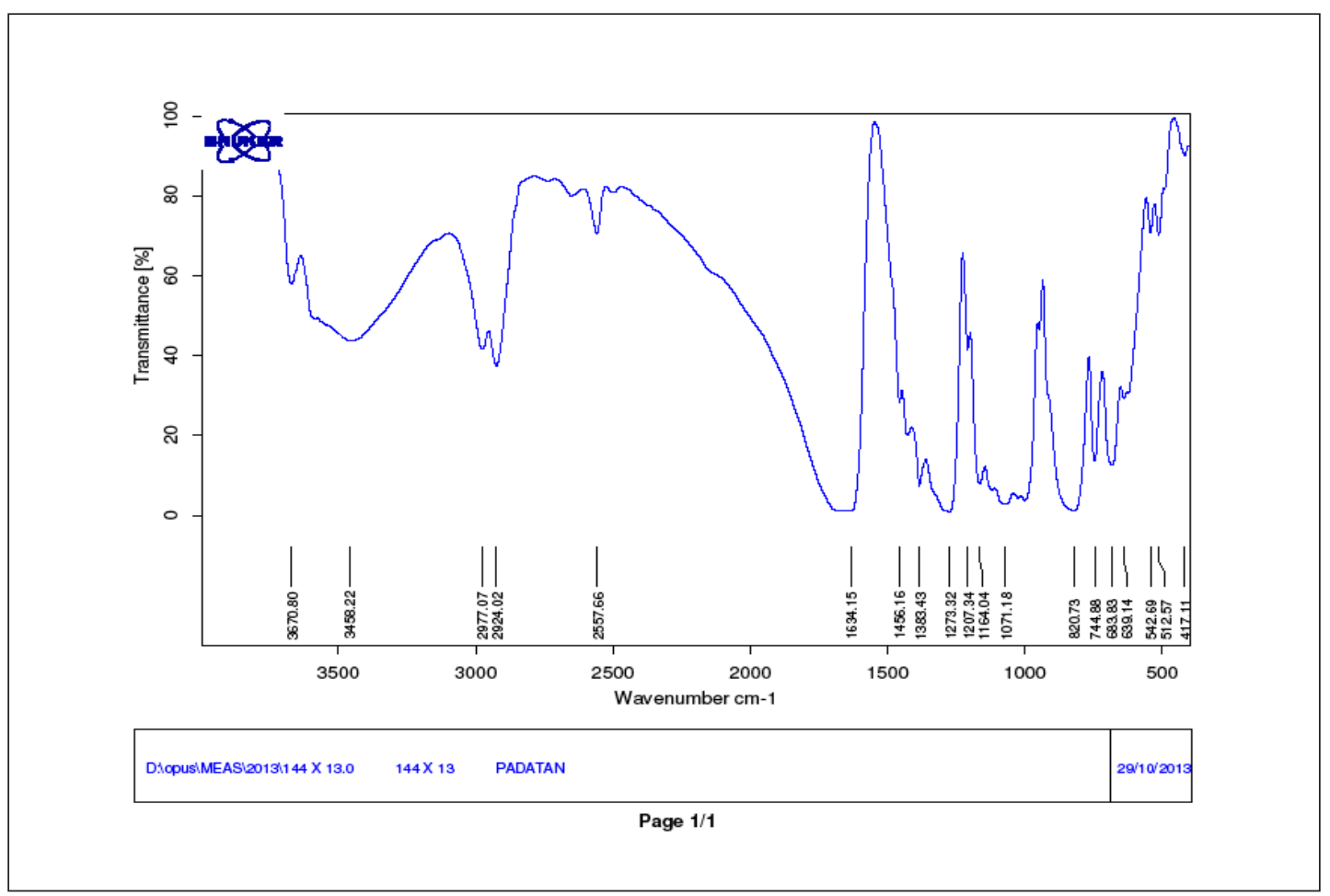

Gambar 5. Kurva FTIR Nitroselulosa Ballmill

\section{KESIMPULAN}

Nitroselulosa dari pulp larut komersial A (berbahan baku kayujarum proses sulfit) dengan perlakuan awal menggunakan blender dan formula $2\left(\mathrm{HNO}_{3}: \mathrm{HNO}_{3}\right.$ fumming: $\mathrm{H}_{2} \mathrm{SO}_{4}$ $=1: 1,25: 4)$, menghasilkan kadar nitrogen yang paling tinggi diatas $12,5 \%$ daripada nitroselulosa dari pulp larut B (kayudaun proses kraft) dan C (kayudaun proses sulfit), yang menunjukkan bahwa nitroselulosa dari pulp larut A dapat digunakan sebagai bahan oksidator pada pembuatan PNC (Propellant Nitro Cellulose). Berdasarkan hasil uji nyala nitroselulosa dari ketiga jenis pulp larut dengan tiga perlakuan awal dan dua formula memenuhi spesifikasi smokeless. Selain itu hasil uji gugus fungsi menggunakan FTIR menunjukkan adanya gugus nitro.

\section{UCAPAN TERIMA KASIH}

Penulis mengucapkan terima kasih kepada Balai Besar Pulp dan Kertas atas kesempatan yang diberikan pada penelitian ini bersama dengan Endang Ruchyat CC S.Ag, juga kepada Ir. Yusup Setiawan M.Eng yang telah memberikan pengalamannya.

\section{DAFTAR PUSTAKA}

Amin, M., Flowers, T.H., 2004. Evaluation of Kjeldahl Digestion Method. Journal of Research, Vol.15(2): 159-179

Christoffersson, Kristina Elg., 2005. Dissolving Pulp - Multivariate Characterisation and Analysis of Reactivity and Spectroscopic PropertiesI. Tesis, Department of Chemistry, Organic Chemistry. Swedia: Umeå University Flickinger, P., Lammi, L., Ernerfeld, B., 2011. Dissolving Pulp. PEERS. Metso Company.

Hartaya, K., 2009. Penguasaan Teknologi Pembuatan Propellant Double base. LAPAN. Bogor: Pusat Teknologi Dirgantara Terapan LAPAN

Hartaya, K., 2010. Korelasi Kadar Nitrogen Dalam Nitroselulosa. Bogor: Pusat Teknologi Dirgantara Terapan LAPAN

Hartaya, K., 2010. Pembuatan Nitroselulosa dari Bahan Selulosa Sebagai Komponen Utama Propelan Double Base. Bogor: Pusat Teknologi Dirgantara Terapan LAPAN

Jahan, S. M., Ahsan, L., Noori, A., Quaiyyum, M. A., 2008. Process for The Production of dissolving pulp from Trema orientalis (Nalita) by Prehydrolisis Kraft and Soda Ethyldiamine (EDA) Process. BioResources, $3(3), 816-828$ 
Miranda, Padil, Yelmida., 2006. Pembuatan Nitroselulosa dari Selulosa- $\alpha$ Limbah Pelepah Sawit Dengan Variasi Waktu Nitrasi dan Rasio Bahan Baku Terhadap Asam Penitrasi. Pekanbaru: Jurusan Teknik Kimia Universitas Riau

Pourmortazavi, S.M., Hosseini, S.G., RahimiNasrabadi, S.S., S.S. Hajimirsadeghi, S.S., Homenian, H., 2009. Effect of nitrate content on thermal decomposition of nitrocellulose. Journal of Hazardous Materials 162(23):1141-1144

Purnawan, 2010. Optimasi Proses Nitrasi pada Pembuatan Nitro Selulosa dari Serat Limbah Industri Sagu. Jurnal Rekayasa Proses, 4(2), 30-34

Setiawan, Y., 2009. Pulp larut dari Kayu Acacia Mangium dan Kenaf Dengan Proses BioBleaching Untuk Pembuatan Nitroselulosa Sebagai Bahan Propelan. Laporan akhir kegiatan penelitian program riset insentif DIKNAS. Bandung: Balai Besar Pulp dan Kertas Kementrian Perindustrian (BBPKKEMENPERIN)
Sixta, H., 2006. Handbook of Pulp Volume 2:102. Strunk, P., 2012. "Characterization of cellulose pulps and the influence of their properties on the process and production of viscose and cellulose ethers". Thesis, Department of Chemistry. Swedia: Umeå University

Vogelsanger, B., Sopranetti, R., 2010. The New Nato Standard For Nitrocellulose Testing, STANAG $41782^{\text {nd }} e d$. Rheinmetall Nitrochemie

Wibowo, H. B., 2005. Potensi Pabrikasi Propelan Homogen di Indonesia. Bogor: Pusat Teknologi Dirgantara Terapan LAPAN.

Wirayuda, J., 2011. Pembuatan Nitroselulosa dari Reject Pulp. Prosiding SNTK TOPI 5:23-26. Pekanbaru 